\title{
Production of volatile fatty acids as a result of bacterial interactions in the cecum of gnotobiotic rats and chickens fed a lactose-containing diet
}

Odette SZYLIT, J. DABARD, Michelle DURAND $\left({ }^{*}\right)$, Christiane DUMAY $\left({ }^{*}\right), M$. BENSAADA, P. RAIBAUD

Summary. Volatile fatty acid (VFA) productions from lactose and lactate by a Clostridium butyricum and a Veillonella alcalescens strain, alone or in combination with a Lactobacillus acidophilus strain, were determined both in vitro in culture media and in vivo in the ceca of gnotobiotic animals. Gnotobiotic rats, which possess intestinal lactase, and chickens, which are devoid of it, were used. Both animal species were fed a diet containing $4 \%$ lactose. The in vitro results showed that the $C$. butyricum strain fermented lactose and $D$-lactic acid to butyric and acetic acids, whereas L-lactic acid was not fermented. The $V$. alcalescens strain did not ferment lactose and fermented $L$ better than $D$-lactic acid. The in vivo results showed that high VFA concentrations were obtained in the ceca of chickens either diassociated with $V$. alcalescens or $C$. butyricum and Lactobacillus strains or monoassociated with $C$. butyricum. VFA concentrations in the ceca of rats were low, whatever strain the rats harbored. In addition, an antagonistic effect of the $C$. butyricum strain against the Lactobacil/us strain was evidenced both in rats and chickens. It is suggested that the absence of a host lactase makes the chick a good model for lactose intolerance studies in human newborns.

\section{Introduction.}

The addition of large amounts of lactose (up to $20 \%$ ) to the diet increases bacterial fermentation in the large intestine and cecum of monogastric animals. In chickens Moroshita et al. (1982) have reported a lowered $\mathrm{pH}$ in the cecal contents. In rats Demigné et al. (1980) have shown that lactic and volatile fatty acids (VFA) are responsible for this acidification. However, it has not been established whether a lower amount of lactose, similar to that present in human milk $(6 \%)$, induces the same fermentation process. The process may be different in rats which exhibit lactase activity (Dahlquist and Thomson, 1964) and in chickens which do not (Siddons, 1969 ; Siddons and Coates, 1972). Therefore, both gnotobiotic rats and chickens, fed a diet containing $4 \%$ lactose, were used to study the effect of interactions between the host and bacteria on cecal lactose fermentation. 
In the present study, we used two strains of strictly anaerobic bacteria belonging to the monogastric intestinal microflora which produce VFA in vitro. either directly from lactose (like Clostridium butyricum) or from lactic acid (like Veillonella alcalescens) (Bergey, 1984). The strains were tested in vitro to assess their fermentative potential. They were then inoculated into germfree animals to determine whether each strain would produce the same acids in vivo and whether there was a synergy between each of them and a lactose-fermenting Lactobacillus strain, LEM 220, which produces D and L-lactic acid (Szylit et al., 1980).

\section{Material and methods.}

Animals and diets. - Axenic chicks of the Warren breed were obtained as previously described (Le Coz et al., 1977) and reared in plastic isolators fitted with a rapid transfer system (La Calhène, Vélizy, France). Axenic adult Fischer rats were kept in the same isolators. These animals were inoculated per os with $1 \mathrm{ml}$ (rats) or with a few drops (chicks) of bacterial cultures containing $10^{8}$ viable cells per $\mathrm{ml}$. All gnotobiotic animals and their conventional counterparts received an experimental diet including $23 \%$ fish meal, $65.4 \%$ maize starch, $4 \%$ maize oil, $4 \%$ lactose, $2 \%$ cellulose, $0.4 \%$ methionine, $1.2 \%$ mineral and vitamin mixture (Szylit and Charlet, 1981). The animals were fed ad libitum. The diet was pelleted and vacuum-sterilized by irradiation at $40 \mathrm{kgy}$.

Bacterial strains and counting media. - The $V$. alcalescens strain was isolated from a rat cecum and the $C$. butyricum strain from the feces of a human newborn suffering from enterocolitis necroticans. These strains were subcultured in medium LYPT containing ( $\mathrm{g} /$ /iter) : yeast extract (Difco Laboratories, Detroit), 10 ; tryptone (Difco), 10 ; peptone (Evans Laboratories, England), 15 ; Tween 80 (Merck), $1 ; \mathrm{pH} 6.5$. The L. acidophilus strain, LEM 220, isolated from a cock crop, was grown on medium LYPT admixed with $10 \mathrm{~g}$ of glucose per liter. For non-selective bacterial counts, 10 -fold dilutions of an aliquot of cecal content from monoassociated animals were mixed with melted solid medium GAPTg.10, $\mathrm{pH} 6.5$ (Raibaud et al., 1973) and placed in long tubes $(8 \times 400 \mathrm{~mm})$. For selective bacterial counts in samples from diassociated animals, $V$. alcalescens was counted in medium $\mathrm{C}, \mathrm{pH} 7.0$, and $C$. butyricum in medium $\mathrm{D}, \mathrm{pH} 7.8$ (Raibaud et al., 1966). All media were incubated for 4 days at $37^{\circ} \mathrm{C}$.

In vitro bacterial cultures. - The two strictly anaerobic bacteria (C. butyricum and $V$. alcalscens) were grown in the basal media LYPT 80 (Raibaud et al., 1966) with lactose and lactate added or not (see table 1). To prereduce the cell media, the tubes were put in a boiling water bath for $30 \mathrm{~min}$, promptly cooled, inoculated with $2 \%$ of a preculture containing $10^{6}$ viable cells per $\mathrm{ml}$, and sealed with an agar plug. Incubation lasted for $24 \mathrm{~h}$ at $40^{\circ} \mathrm{C}$ under stirring.

Biochemical determinations. - Cecal contents were collected from chickens and rats sacrificed by chloroform. $\mathrm{pH}$ was measured with a microelectrode. Aliquots of cecal contents or culture media were deep-frozen in liquid nitrogen with 


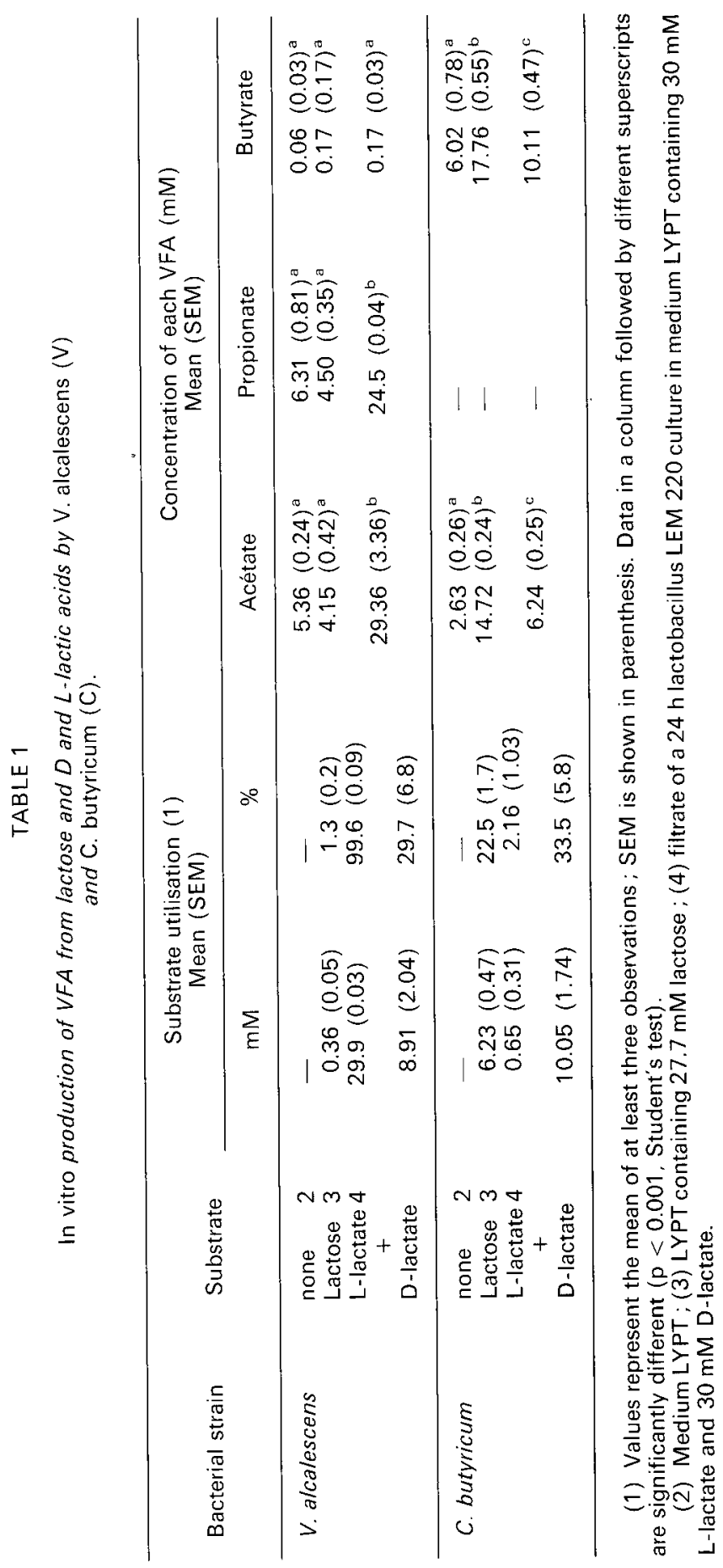


mercuric chloride. The samples were centrifuged and the supernatants were deproteinized using phosphotungstic acid $(0.4 \mathrm{ml}$ of saturated solution for $2 \mathrm{~g}$ of content) for $16 \mathrm{~h}$ at $0{ }^{\circ} \mathrm{C}$, then cold-centrifuged before VFA determination by gas-liquid chromatography (Ottenstein and Bartley, 1971). Temperature parameters were fixed at $115^{\circ} \mathrm{C}$ for the oven, $170^{\circ} \mathrm{C}$ for the injector and $160^{\circ} \mathrm{C}$ for the detector. Nitrogen was used as carrier gas. To prevent early ageing of the column, we used the precolumn recommended by Jouany (1982). Isobutyric acid was chosen as the internal standard because of its low concentration in the physiological media studied and its good retention time in the column.

Lactose, D- and L-lactic acids were determined enzymatically (UV, Boehringer method) on another aliquot of culture media.

Statistical analysis. - The means were compared using Student's t-test.

\section{Results.}

In vitro production of VFA by strictly anaerobic strains (tabl. 1).

In the absence of lactose or lactate, the VFA production of the two anaerobic strains was not significantly different. Lactose supply significantly increased $(P<$ 0.001 ) VFA production by the Clostridium strain, whereas the Veillonella strain did not metabolize lactose. In the filtrate of LEM 220 culture containing $30 \mathrm{mM}$ of both D- and L-lactate, D-lactate was partly metabolized by each strain (about $30 \%$ ), while L-lactate was only metabolized by the Veillonella strain. Consequently, VFA production by $V$. alcalescens was 4 -fold higher than that of $C$. butyricum.

Cecal population size of the different bacterial strains in gnotobiotic animals (tabl. 2).

The Lactobacillus strain became established at a similar level in both monoassociated rats and chickens. The size of the $V$. alcalescens population was large and almost similar in both animal species, either when the strain was used alone or in combination with the Lactobacillus strain. No interaction occurred between the above two strains since the population levels of the latter were not significantly different in monoassociated and diassociated rats and chickens. The C. butyricum strain became established at a similar level both in monoassociated and diassociated animals and significantly repressed the Lactobacillus strain in both chickens $(P<0.01)$ and rats $(P<0.001)$.

Effect of bacterial strains and host on cecal VFA concentrations (tabl. 3).

In axenic animals cecal concentrations of VFA were low, particularly in rats where only trace amounts of acetate were detected. Trace amounts of propionic and butyric acids were also detected in axenic chickens but not in rats. On the contrary, VFA productions were high in conventional rats and chickens. However, in conventional chickens cecal VFA concentration was 2-fold lower than in conventional rats, but the $\mathrm{pH}$ values $(6.6 \pm 0.10$ vs $6.9 \pm 0.08)$ were not significantly different. 


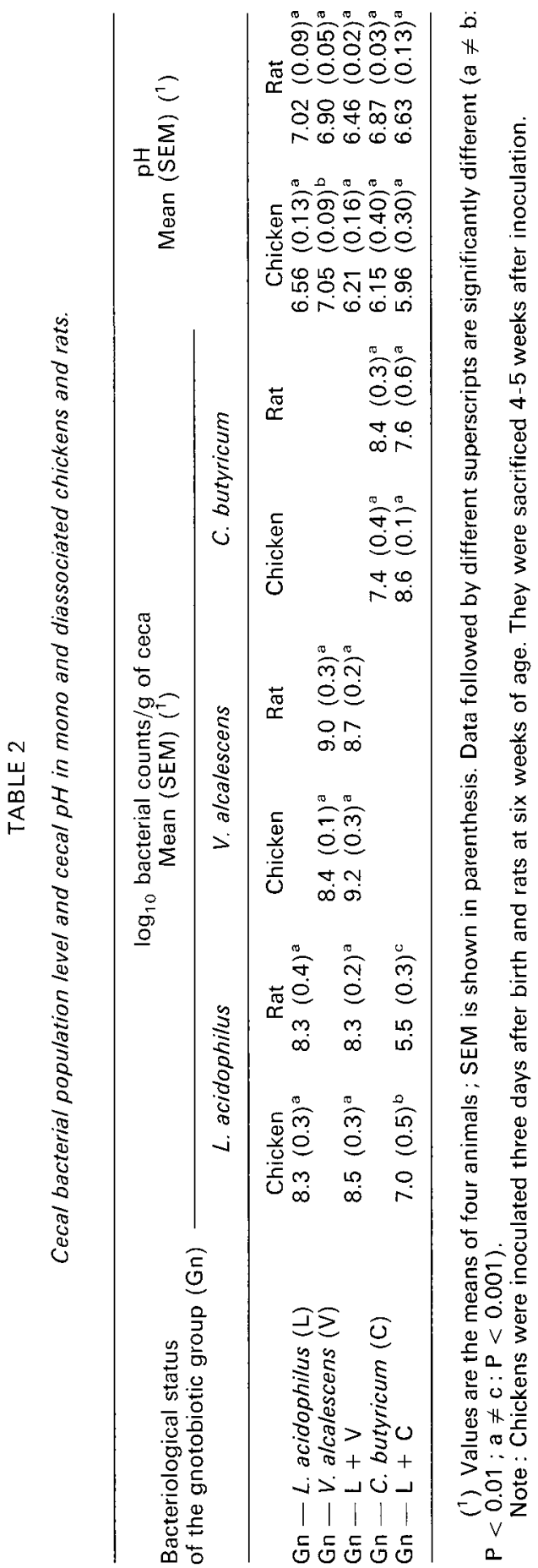




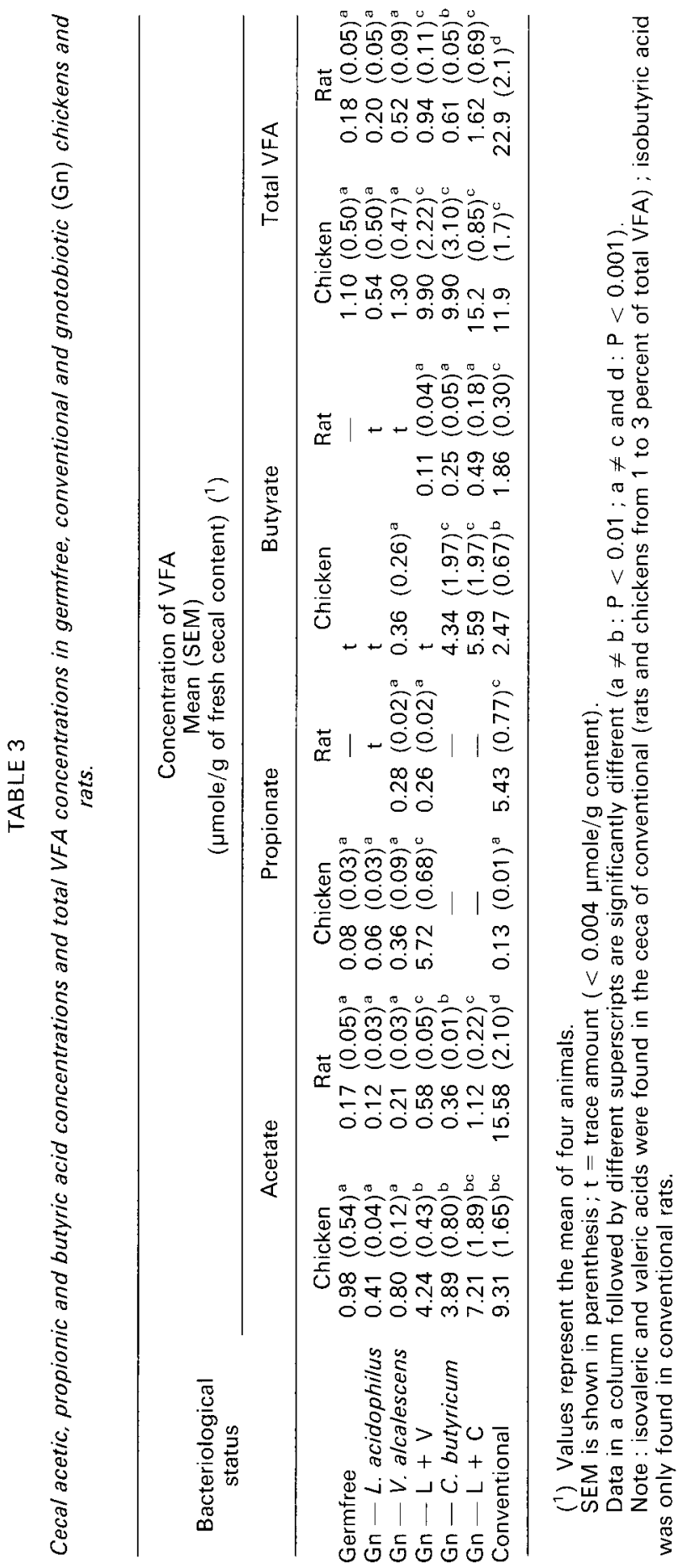


The ceca of rats and chickens monoassociated with Lactobacillus strains or $V$. alcalescens strains did not contain large amounts of VFA, although cecal propionic acid concentrations were slightly increased in animals monoassociated with $V$. alcalescens as compared to those measured in axenic animals or in animals monoassociated with the Lactobacillus strain. Cecal pH values (tabl. 2) were not significantly different from those obtained in axenic chickens $(6.96 \pm 0.40)$ and rats $(6.72 \pm 0.01)$. By contrast, there was a striking difference between rats and chickens monoassociated with $C$. butyricum. In the former, cecal total VFA concentrations were only slightly higher than in their axenic counterparts and cecal $\mathrm{pH}$ was similar to that of axenic rats. In the latter, cecal VFA concentrations were 8-fold higher than in axenic chickens and butyrate concentrations exceeded those of conventional chickens. The cecal $\mathrm{pH}$ was slightly, but not significantly, lower as compared to their axenic counterparts.

In chickens diassociated with Lactobacillus and $V$. alcalescens strains a significant synergy between the two strains was seen since cecal total VFA concentrations were 10 -fold higher and cecal $\mathrm{pH}$ significantly lower than in chickens monoassociated with $V$. alcalescens strain. In chickens diassociated with Lactobacillus and $C$. butyricum strains, cecal VFA concentrations were not significantly higher than in those monoassociated with $C$. butyricum. A slight synergy was also observed in rats diassociated with Lactobacillus and $C$. butyricum or $V$. alcalescens strains since cecal total VFA concentrations significantly increased compared to their monoxenic counterparts.

\section{Discussion.}

Our in vitro results, showing that the $V$. alcalescens strain produced acetic and propionic acids mainly from $L$-lactate, but not from lactose, are consistent with those of Schwartz and Gilchrist (1975), who found that a similar strain isolated from cow rumen content dit not metabolize lactose, and with those of Ogimoto and Giesecke (1974) who found that a strain isolated from sheep rumen content metabolized $93 \%$ of L-lactate and $23 \%$ of D-lactate. The preferential utilization of D-lactate rather than L-lactate by the $C$. butyricum strain has not been reported previously. The differences between the cecal VFA concentrations observed in axenic and conventional rats and chickens confirm the bacterial origin of these metabolites, as already observed by Rémésy and Demigné (1976) in rats and by Annison et al. (1968) in chicks. However, we found trace amounts of propionate and butyrate in axenic chickens, which were not seen by the latter authors. A dietary origin could be suspected rather than an endogenous one. However, the role of bacteria remains preponderant in the production of cecal VFA. Although cecal VFA concentrations were 2-fold lower in chickens than in rats, cecal $\mathrm{pH}$ was not significantly different. Thus, VFA did not modify cecal $\mathrm{pH}$ to a great extent, probably due to the highly buffered system.

In mono- and diassociated chickens, our results are in good agreement with those obtained in the culture media. As chickens do not possess intestinal lactase, lactose reaches the cecum and can be metabolized to VFA only by $C$. butyricum 
which produces acetic and butyric acids. The butyric acid concentrations in conventional and $C$. butyricum monoassociated chickens were not significantly different, although predominant cecal bacteria from conventional chickens are not high producers of butyric acid. The sole difference between the axenic and $V$. alcalescens mono-associated chickens was a slight cecal production of propionic acid by $V$. alcalescens, probably coming from endogenous L-lactic acid.

In diassociated chickens, our results show that the Lactobacillus strain produced lactic acid which was metabolized into acetic and propionic acids by the Veillonella strain, as in culture media. Propionic concentration was 2-fold higher in diassociated than in conventional chickens. Cecal concentration of butyric acid in chickens diassociated with C. butyricum and Lactobacillus was not significantly higher than in $C$. butyricum monoassociated chickens. This could be related to the repression of the Lactobacillus population size observed in the present experiment. Indeed, it may be supposed that lactose was preferably metabolized by the $C$. butyricum which is not able to metabolize lactic acid to a great extent.

Our results obtained on mono and diassociated rats confirmed that lactose was well hydrolysed by the intestinal lactase since only a slight increase in total VFA concentration was observed compared to the germfree rats. The VFA produced in conventional rats presumably did not come from the dietary lactose, but from other types of non-digestible carbohydrates fermented by the many other bacterial strains present in the cecum. Kim, Benerenga and Grummer (1978) observed that $43 \%$ of the lactose consumed became available for fermentation with a diet containing $30 \%$ lactose. Therefore, it is only when the diet contains a high level of lactose that a substantial fraction of the lactose ingested is available for fermentation.

The observation of the antagonistic effect of the $C$. butyricum strain against the Lactobacillus strain in both diassociated groups is noteworthy. This effect was more pronounced in diassociated rats than in chickens where cecal VFA concentration was 6 to 8 -fold higher. Therefore, it is more likely that this antagonism was not related to VFA concentration. The competition for lactose could explain this, especially as the lactose was better absorbed in rats than in chickens and therefore less available for microbiological degradation.

Our findings show that the experimental models used were reliable for a study of in vivo bacterial VFA production by specified strains, the effect of host and diet, and the bacterial competition for limiting substrates. The absence of a host lactase could make the chick a good model for studies of lactose intolerance and its consequences on the infectious pathology of the human colon. Recently, lesions similar to those produced by neonatal necrotizing enteritis, and related to lactose fermentation, have been observed in the ceca of monoxenic chicks inoculated with a $C$. butyricum of human newborn origin (Popoff et al., 1985).

Reçu en janvier 1988. Accepté en juin 1988.

Acknowledgements. -- The authors thank Annick Bouroche for the English translation. 
Résumé. Synergie entre deux souches bactériennes pour la production d'acides gras volatils dans le caecum du poulet et du rat gnotoxénique nourris avec un régime contenant du lactose.

La fermentation du lactose et du lactate en acides gras volatils (AGV) par deux souches bactériennes d'origine digestive est étudiée à la fois in vitro, et in vivo dans les caeca d'animaux gnotoxéniques. Les souches de Clostridium butyricum et de Veillonella alcalescens sont utilisées seules (groupes monoxéniques) ou en association avec une souche de Lactobacillus acidophilus (groupes dixéniques). Deux espèces animales sont comparées : le rat qui possède une lactase intestinale et le poulet qui en est dépourvu. Tous les animaux ont reçu un régime contenant $4 \%$ de lactose.

Les résultats in vitro montrent que la souche de $C$. butyricum fermente le lactose et l'isomère $\mathrm{D}$ de l'acide lactique en acide acétique et butyrique. La souche $V$. alcalescens ne fermente pas le lactose mais fermente l'acide lactique surtout sous sa forme $L$ en acide acétique et propionique. In vivo, ces acides gras volatils sont formés dans les caeca des poulets monoxéniques- $C$. butyricum et dans les deux groupes dixéniques. Dans les caeca des rats monoxéniques et dixéniques les concentrations en $A G V$ restent très faibles. On relève un effet antagoniste de la souche $C$. butyricum sur le niveau d'implantation des lactobacilles à la fois chez le rat et le poulet. Ces résultats suggèrent que le poulet dépourvu de lactase intestinale pourrait être un bon modèle pour les études des intolérances au lactose chez le nouveau-né humain.

\section{References}

ANNISON E. F., HILL K. J., KENWORTHY R., 1968. Volatile fatty acids in the digestive tract of the fowl. Br. J. Nutr., 22, 207-216.

BERGEY'S, 1974. Manual of determinative bacteriology. 8th ed. BUCHANAN R. E. \& GIBBONS N. E. co-ed. The Williams \& Wilkins Co/Baltimore USA, pp. 446.

DAHLQUIST A., THOMSON D. L., 1964. The digestion and absorption of lactose by the intact rat. Acta physiol. scand., 61, 20-33.

DEMIGNÉ C., RÉMÉSY C., RAYSSIGUIER Y., 1980. Effect of fermentable carbohydrate on volatile fatty acids, ammonia and mineral absorption in the rat caecum. Reprod. Nutr. Dévelop., 20. $1351-1359$.

JOUANY J. P., 1982. Volatile fatty acid and alcohol determination in digestive contents, silage juices, bacterial cultures and anaerobic fermenter contents. Sci. Aliments, 2, 131-144.

KIM K. I., BENEVENGA N. J., GRUMMER R. H., 1978. Estimation of the fraction of the lactose in a high lactose diet available for fermentation in the cecum and colon of the rat. J. Nutr., 108, 79-89.

LE COZY., SZYLIT O., DUCLUZEAU R., 1977. Mise au point des isolateurs de plastique souple pour des expériences nutritionnelles pour poulet axénique et gnotoxénique. Sci. Tech. Anim. Lab., 2, 27-33.

MOROSHITA Y., FULLER R., COATES M. E., 1982. Influence of dietary lactose on the gut flora of chicks. Br. Poult, Sci., 23, 349-359.

OGIMOTO K., GIESECKE D., 1974. Untersuchungen zur Genese und Biochemie der Pansenacidose Microorganismen und Umsetzung von Milchsaüre-Isomeren. Zbl. Vet. Med., A, 532-538.

OTTENSTEIN D. M., BARTLEY D. A., 1971. Separation of free acids $C_{2}-C_{5}$ in dilute aqueous solution column technology. J. Chromatogr. Sci., 9, 673-681.

POPOFF M. R., SZYLIT O., RAVISSE P., DABARD J., OHAYON H., 1985. Experimental cecitis in gnotoxenic chickens monoassociated with Clostridium butyricum strains isolated from patients with neonatal necrotizing enterocolitis. Infect. Immun., 47, 697-703.

RAIBAUD P., DICKINSON A. B., SACQUET E., CHARLIER H., MOCOUOT G., 1966. La microflore du tube digestif du rat I Techniques d'étude et milieux de culture proposés. Ann. Inst. Pasteur (Paris), 110, 568-590. 
RAIBAUD P., GALPIN J. V., DUCLUZEAU R., MOCQUOT G., OLIVIER G., 1973. Le genre lactobacillus dans le tube digestif du rat $\mathrm{I}$. Caractères des souches homofermentaires isolées de rats holo et gnotoxéniques. Ann. Inst. Pasteur (Paris), 124A, 83-109.

RÉMÉSY C., DEMIGNÉ C., 1976. Partition and absorption of volatile fatty acids in the alimentary canal of the rat. Ann. Rech. vét., 7, 39-55.

SCHWARTZ H. M., GILCHRIST F. M. G., 1975. Microbial interactions with the diet and the host animal, 165-179. In I.W. Mc DONALD and A.C.I. WARNER, Digestion and metabolism in the ruminant. Univ. New-England Publ. Unit, Armidale, Australia.

SIDDONS R. C., 1969. Intestinal disaccharidase activities in the chicks. Biochem. J., 112, 51-59.

SIDDONS R. C., COATES M. E., 1972. The influence of the intestinal microflora on dissacharidase activities in the chicks. Br. J. Nutr., 27, $101-112$.

SZYLIT O., CHAMP M., AIT-ABDELKADER N., RAIBAUD P., 1980. Rôle des souches de lactobacilles sur la dégradation des glucides chez le poulet monoxénique. Reprod. Nutr. Dévelop., 20, $1701-1706$.

SZYLIT O., CHARLET G., 1981. Energy and protein retention in holoxenic, axenic and gnotoxenic chickens monoassociated with Lactobacillus spp. Br. Poult. Sci., 22, 305-315. 